\title{
Invasive Prunus serotina - a new host for Yponomeuta evonymellus (Lepidoptera: Yponomeutidae)?
}

\author{
Piotr KAROLEWSKI ${ }^{1}$, ANdRZej M. JAGODZIŃSKI ${ }^{1,2}$, MARIAn J. GIERTYCH ${ }^{1,3}$, AdRIAN ŁUKOWSKI ${ }^{2}$, \\ EDWARD BARANIAK ${ }^{4}$ and JACEK OLEKSYN ${ }^{1}$
}

\author{
${ }^{1}$ Institute of Dendrology, Polish Academy of Sciences, Parkowa 5, 62-035 Kórnik, Poland; e-mail: pkarolew@man.poznan.pl \\ ${ }^{2}$ Department of Forest Protection, Faculty of Forestry, Poznań University of Life Sciences, Wojska Polskiego 71c, 60-625 Poznań, \\ Poland; e-mail:amj@man.poznan.pl \\ ${ }^{3}$ Faculty of Biological Sciences, University of Zielona Góra, Prof. Z. Szafrana 1, \\ 65-516 Zielona Góra, Poland; e-mail: giertych@man.poznan.pl \\ ${ }^{4}$ Department of Systematic Zoology, Faculty of Biology, Adam Mickiewicz University, Umultowska 89, 61-614 Poznań, Poland; \\ e-mail: baraniak@amu.edu.pl
}

Key words. Lepidoptera, Yponomeutidae, Yponomeuta evonymellus, ermine moth, folivorous insect, defense compounds, phenols, tannins, native and invasive species, Prunus padus, P. serotina

\begin{abstract}
Introduction of non-native species of plants affects the existence and feeding preferences of herbivorous insects. The bird cherry ermine moth (Yponomeuta evonymellus) is considered a typical monophagous insect, which feeds only on bird cherry (Prunus padus) leaves. However, in recent years, we have observed Y. evonymellus larvae feeding on leaves of the non-native (in Europe) and highly invasive black cherry (Prunus serotina). We hypothesized that this insect can feed on P. serotina leaves with no negative effects on its growth and development and that the main reason why it does not accept this plant as a host is the phenological difference between the two species of cherry. Moving individuals of the three larval instars (L1, L2 and L3) from bird cherry to black cherry did not affect the percentage of adults that emerged from the pupae or the masses of the moths. In addition, in one experiment, the moths were heavier and the percentage parasitized was lower on P. serotina than on P. padus. Thus, the leaves of black cherry were at least as good a food source as P. padus for Y. evonymellus. During the feeding period, there were low concentrations of defense compounds (phenolics and condensed tannins) in the leaves of both species. However, it is likely that the low success of Y. evonymellus in infesting P. serotina is due to spring frosts and heavy rains, which are deadly for larvae in an early stage of development on black cherry. In the field these weather conditions resulted in a very high mortality of larvae in our experiment. In conclusion, the use of bird cherry as a host by Y. evonymellus is mainly determined by its phenology.
\end{abstract}

\section{INTRODUCTION}

Forest understory plants are a significant source of food for herbivores, including folivorous insects (Leather, 1985; Hamilton et al., 2004). One reason for this is that these plants often grow in the shade and thus their leaves, in comparison with plants that grow in full sun, are characterized by both a less resistant structure (Abrams et al., 1992; Molina-Montenegro et al., 2006) and lower levels of defence compounds (Henriksson et al., 2003; Koricheva et al., 2004). Therefore, understory trees and shrubs are frequently the target of attacks and often the refugia for numerous herbivorous insects (Flecker \& Allan, 1984; Chaneton et al., 2010).

In Europe, a very common and abundant component of understory plants are two species of the genus Prunus, the native bird cherry ( $P$. padus) and non-native black cherry (P. serotina) from North America (Zerbe \& Wirth, 2006; Pairon et al., 2010). European bird cherry is a species native to Europe (Uusitalo, 2004), with a wide range, extending from the southern to the northern parts of Europe (Scholz \& Scholz, 1995; Leather, 1996). Black cherry is native to northeastern and central areas of the USA and Mexico (Fowells, 1965; Pairon et al., 2010). This species is highly invasive in Europe (Knight et al., 2008; Vanhellemont et al., 2009; Pairon et al., 2010). During the early 17th century, Prunus serotina was introduced and planted in European parks and gardens (Starfinger et al., 2003) and in the late 19th century planted in forests on poor sandy soils to increase forest production (Starfinger, 1997). The successful colonization by black cherry is a result of its ability to tolerate relatively dry and nutrient poor soils (Starfinger, 1991; Halarewicz \& Jackowski, 2011).

The leaves of both these species of cherry emerge earlier in spring than those of many other understory plants and are strongly attacked by the following folivorous insects: beetles - mainly Gonioctena species (Coleoptera: Chrysomelidae) (Leather, 1994; Uusitalo, 2004), aphids - Rhopalosiphum padi (Heteroptera: Aphididae) (Leather, 1988) and moths - species of the genus Yponomeuta (Lepidoptera: Yponomeutidae) (Menken et al., 1992; Leather, 1996).

Leaf mass loss of $P$. padus caused by these and other folivorous insects is much higher than that of $P$. serotina growing in shade and direct sunlight (Żmuda et al., 2008; Karolewski et al., 2013). Foliage loss of P. padus due to folivorous insect often reaches $50 \%$ and the almost total 


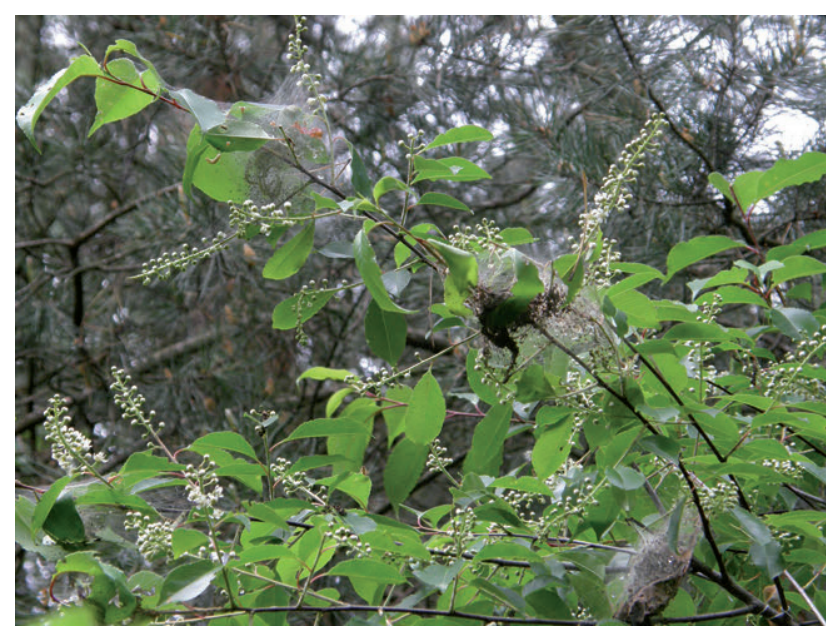

Fig. 1. Larvae of Y. evonymellus feeding on leaves of P. serotina.

defoliation of shrubs is recorded (Leather \& Lehti, 1982; Leather, 1986). Although the leaves of shrubs of $P$. serotina growing in the shade (shade leaves) are more often eaten than those of shrubs growing in full sun (Karolewski et al., 2013) this species is much less abundant in forested understories because it is not tolerant of deep shade $(\mathrm{Pa}-$ quette et al., 2007). This variation in susceptibility of both species to feeding by folivorous insects depending on light conditions is primarily due to differences in leaf structure. The sun leaves of black cherry are leathery, very tough and rigid, and thus mechanically resistant to browsing by insects (Abrams et al., 1992).

The third species of pest considered dangerous, especially to $P$. padus, is the bird cherry ermine moth (Yponomeuta evonymellus, Linnaeus, 1758) (Menken et al., 1992). This insect causes a large loss of leaves and attacks them very early in their development. Leather (1986) considered $Y$. evonymellus to be the only species of the genus Yponomeuta that feeds entirely on bird cherry, stating that it "...is not thought to feed on any other host...". We do not deny the validity of this statement and indeed believe it accurately described the situation during the 1980s. However, in recent years we have observed an increase in the damage to black cherry shrubs caused by $Y$. evonymellus. Based on regular observations over the last 10 years (ca. 1000 shrubs/year), we noted initially a few cases of Yponomeuta evonymellus feeding on black cherry during the growing season and currently, in a forest where both species of cherry are present, $3-5 \%$ of $P$. serotina shrubs are infested with this insect (Fig. 1) (unpubl. data, P. Karolewski - pers. observ.).

Almost all the branches of the black cherry shrubs on which the Yponomeuta evonymellus larvae fed were in contact with bird cherry shrubs. The larvae move from the bird cherry shrubs on which they hatched to black cherry and in recent years this movement of larvae from bird cherry to black cherry has occurred at earlier stages in the development of the larvae.

Bird cherry is more tolerant of low temperatures and its range extends much further north than black cherry

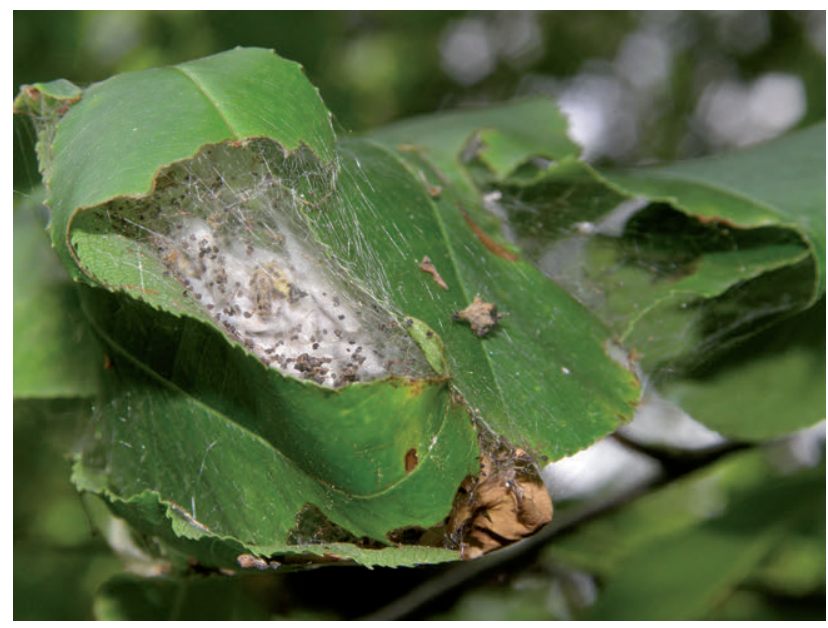

Fig. 2. Pupae of Y. evonymellus on leaves of P. serotina.

(Leather, 1996; Uusitalo, 2004). The larvae of Yponomeuta evonymellus hatch in late summer. In the spring the following year (after winter hibernation), the larvae very quickly emerge from beneath the shields and go directly to the young developing leaves of P. padus (Leather, 1986). Based on our observations over several years the development of $P$. padus leaves usually begins about two weeks (7-20 days) earlier than those of $P$. serotina. Therefore, larvae feeding on bird cherry leaves have the opportunity at an early stage in their development to continue feeding on young delicate leaves by moving and feeding on black cherry leaves. $P$. padus and $P$. serotina are very closely related species and the chemical composition of their leaves is similar. We have also observed that after moving to $P$. serotina, the larvae usually do not return to P. padus, but the larvae pupate (Fig. 2) and adults emerge there. This behavior of the larvae indicates that $P$. serotina leaves are suitable food for them, and at least, as indicated by the results of the research presented in this paper, are not qualitatively worse as a food source than leaves of P. padus. The field observations mentioned above led us to test the hypothesis that $Y$. evonymellus larvae can feed and complete their development equally well on the leaves of $P$. serotina as on those of P. padus. By moving the larvae of $Y$. evonymellus from $P$. padus to $P$. serotina at various stages in their development, we determined the effect of changes in host plant species, and thus the quality of food, on the percentage of moths emerging over time and the total percentage of adults emerging from pupae. We also addressed the question: is the phenological difference or food quality the most important factor determining the choice of $P$. padus as a host plant? In order to do this we defined the difference in hardness of the leaves and their content of defensive compounds (soluble phenols and condensed tannins) for the two species of cherry during the feeding period of larvae.

This is part of a more general hypothesis that when environmental conditions change even insects regarded as monophagous are able to successfully adapt to new host plants. 


\section{MATERIAL AND METHODS}

\section{Insects}

This study was conducted on the bird cherry ermine moth Yponomeuta evonymellus (L.) (Lepidoptera: Yponomeutidae). Depending on the variant tested, we used (1) L1 larvae, that is larvae that are about to leave the egg cluster, (2) L2 larvae (length about $4 \mathrm{~mm}$ ) and (3) L3 larvae (length about $8 \mathrm{~mm}$ ). The clusters of eggs and larvae came from bird cherry shrubs growing in the experimental forest of the Institute of Dendrology at Kórnik (Poland, $52^{\circ} 14^{\prime} \mathrm{N}, 17^{\circ} 05^{\prime} \mathrm{E}$ ). We placed them on either black cherry or other shrubs of P. padus. We did not use mesh bags to confine the larvae as we wanted the conditions to be as close as possible to natural, in particular in that the larvae were free to move and exposed to parasites and predators.

Results of transferring egg clusters (Exp. I, Fig. 3) gave rise to an alternative hypothesis, that the differences in the percentage of adults emerging from pupae on the two species of cherry (Fig. 5) may be due to differences in the incidence of parasitism. Therefore, in this experiment we assessed the degree of pupal parasitism. As the main aim of the study was not to determine the total parasitism of Yponomeuta evonymellus we only determined the percentage of pupae parasitized. In the section on "Experimental design" there is more detailed information on this topic.

\section{Plants}

Two species of understory shrubs, black cherry (Prunus serotina Ehrb.) and European bird cherry (Prunus padus L.), were used in this study. The shrubs of $P$. padus and $P$. serotina were both 3-5 m high and growing under a canopy of Pinus sylvestris L. with an admixture of Quercus robur L., Fagus sylvatica L., Carpinus betulus L. and Ulmus laevis Pall. In each of the three experiments described below 24 shrubs were used (12 specimens of each species of cherry). The shrubs were in the same forest at Kórnik, from which the eggs and larvae of $Y$. evonymellus were collected. Based on our long-term observations the start of leaf growth in $P$. padus and $P$. serotina differed by 7 to 14 days. In 2009-2011, when we carried out the experiments, the difference was 10 days for 2009 and 2010 and 14 days for 2011.

\section{Experimental design}

Over three years three trials were conducted in the experimental forest where the larvae were collected, in the first year using larvae in the last stage of development, then in the second and third years using larvae in the two earlier stages of development. However, in this paper we present the results of the experiments in the reverse chronological order, first for the larvae in the earliest stage of development (Exp. I), followed by the second stage (Exp. II) and finally the last stage of larval development (Exp. III), as shown in Fig. 3.

We used sections of bird cherry shoots with egg clusters in the experiment on L1 larvae in April 2011 (Exp. I), with L2 larvae in April 2010 (Exp. II) and L3 larvae in April 2009 (Exp. III). For Exp. I, shoots (10-15 cm long) bearing clusters of eggs were collected in autumn, 2010. These shoots were overwintered placed vertically in trays filled with sand and covered with a plastic mesh, which provided them with good ventilation and protection from insectivorous birds. Sections of shoots with egg clusters were tied by nylon thread in spring to places on shrubs where eggs are typically laid (short lateral shoots, short twigs) at the time the larvae of this species start feeding (Fig. 3). In Exp. I, shoots with egg clusters were placed on cherry shrubs on 3 April, the day on which the larvae began to leave the egg clusters and move to leaf buds (on the 12 shrubs of each cherry species). In this experiment, using the same $P$. serotina shrubs, shoots with egg clusters were also placed on cherry shrubs on 17 April to determine the effect

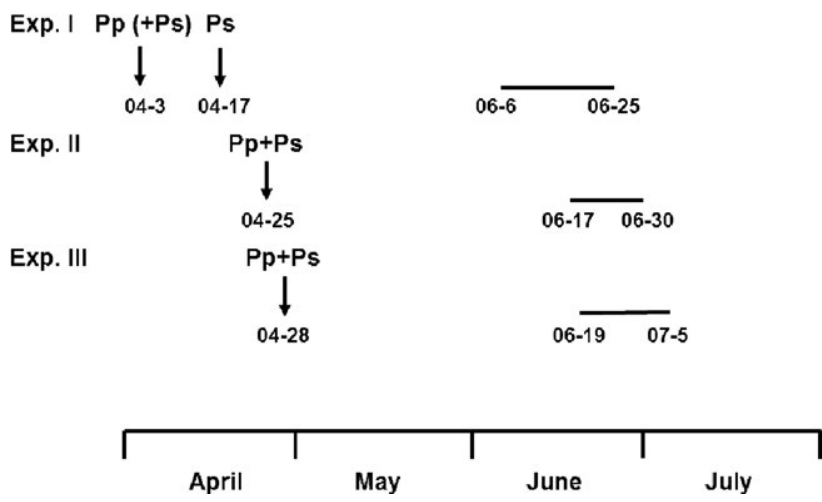

Fig. 3. Outline of the experiments in which first instar larvae L1 (Exp. I), L2 (Exp. II) and L3 larvae (Exp. III) were fed on either P. padus (Pp) or P. serotina (Ps). Vertical arrows indicate the dates on which the larvae were placed on shrubs and the horizontal lines the time periods over which moths were recorded emerging from batches of pupae. Further details are in the "Experimental design" section of the Material and Methods.

of the difference in the stage of leaf development of the two species of cherry at the start of larval feeding. The shoots with egg clusters used on 17 April were previously stored from 15 March until transferred to the experimental site in a refrigerator at +7 to $10^{\circ} \mathrm{C}$. In experiments in which larvae at a later stage of development (Exp. II and III) were used the larvae were transferred to other shrubs of bird cherry or black cherry (12 shrubs per species) on the second day after sampling. In all experiments, the larvae fed on leaves for 6-7 weeks unprotected from predators. When the larvae pupated at the beginning of June, the pupae were transferred to the laboratory (on 1 June in Exp. I, and on 5 June in Exp. II and Exp. III) and the time to adult emergence and percentage adult emergence were recorded. Shoots with bunches of pupae were cut from the shrubs and placed in one-liter plastic containers with holes drilled in the lids and lower sidewalls for ventilation, which were kept in the laboratory at room temperature. Newly emerged moths were counted, removed and killed with ethyl acetate each day. Approximately $18 \mathrm{~h}$ after they were killed the mass and gender of the moths was determined. Each of the experiments ended when no new moths emerged for a period of one week. Then we separated and counted the number of pupae. As in Exp. I there were very big differences in the percentage of adults that emerged from the pupae, so at the end of the experiment we not only separated and counted all the pupae, but also cut each of them open in order to determine the number and percentage parasitized. We did not identify the parasites.

\section{Chemical analysis and additional measurements}

The basic chemical composition of leaves (nitrogen concentration, total non-structural carbohydrates, soluble phenolic compounds and condensed tannins) and differences in the leaves of the two species of cherry were determined in previous studies (Żmuda et al., 2008; Karolewski et al., 2013). However, for this study, we also analyzed the contents of defensive compounds (soluble phenolics and condensed tannins) at four points in time over the period when the larvae of $Y$. evonymellus feed on leaves (mid-April to mid-June). The leaves of three shrubs of each cherry species, selected from among those used for Exp. I, were analyzed.

Total soluble phenols and condensed tannins in dried leaf tissue $\left(40^{\circ} \mathrm{C}\right.$ for tannins and $65^{\circ} \mathrm{C}$ for other phenols), ground in a Mikro-Feinmühle-Culatti mill (IKA Labortechnik Staufen, Germany), were analyzed. 

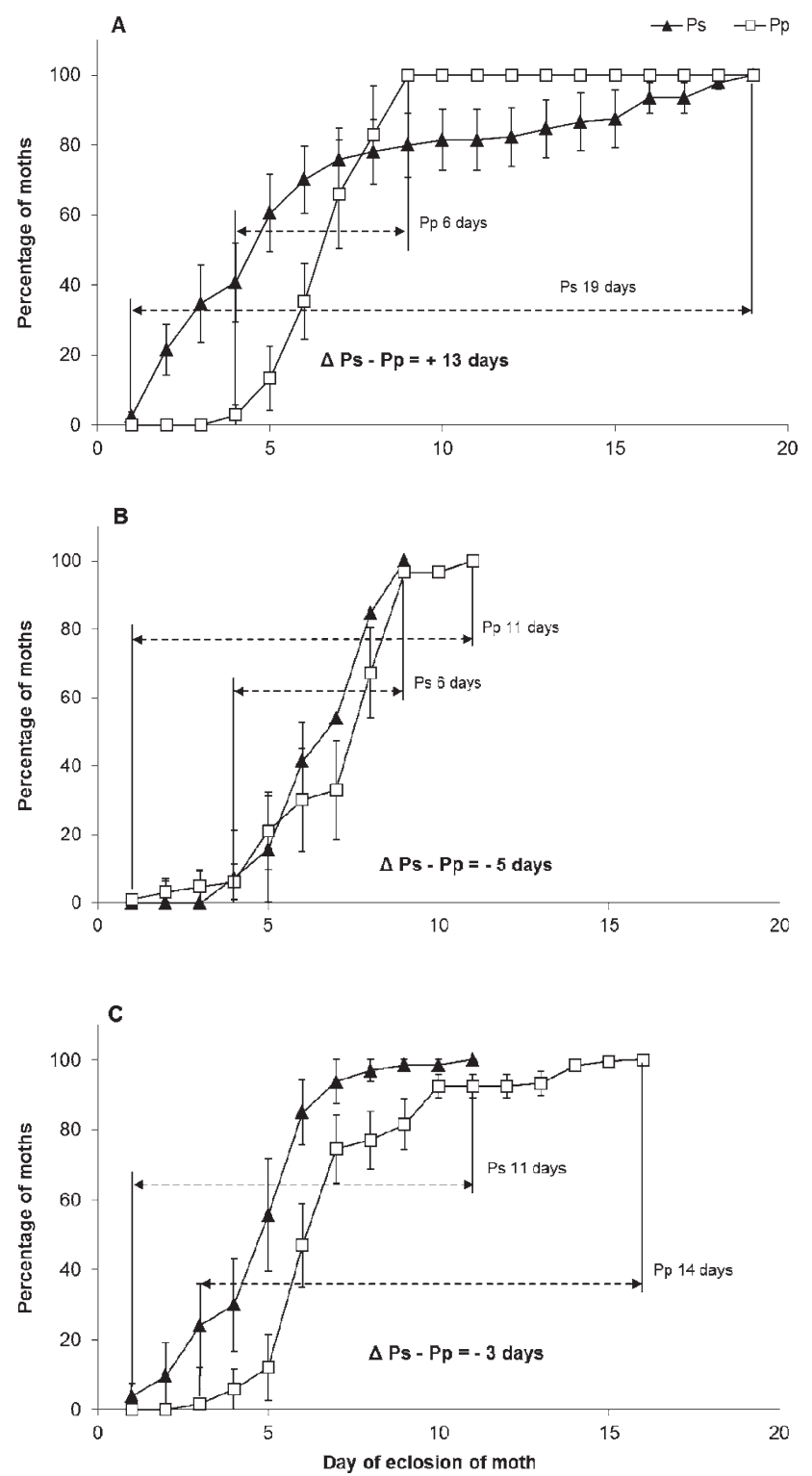

Fig. 4. Cumulative daily percentage of moths that emerged expressed in terms of the total number that emerged, which is $100 \%$, in Exp. I (A), Exp. II (B) and Exp. III (C), in which L1 instar larvae (Exp. I), L2 (Exp. II) and L3 (Exp. III) were fed on either leaves of $P$. padus $(\mathrm{Pp})$ or $P$. serotina $(\mathrm{Ps})$. A repeated measures ANOVA was used to assess the effect of plant species (S), time $(\mathrm{T})$ and the interaction $\mathrm{S} \times \mathrm{T}$ on percentage of moths that emerged. For A: (S) $P=0.95$, (T) $P<0.0001$, $(\mathrm{S} \times \mathrm{T}) P<0.001$, for B: (S) $P=0.941$, (T) $P<0.0001$, $(\mathrm{S} \times \mathrm{T}) P=0.65$, and for $\mathrm{C}$ : (S) $P=0.005$, (T) $P<0.0001,(\mathrm{~S} \times \mathrm{T}) P=0.78$. Vertical bars represent standard errors (SE).

The content of phenolic compounds (TPh) was measured colorimetrically $(\lambda=660 \mathrm{~nm})$ using Folin and Ciocalteu's Phenol Reagent (SIGMA F-9252) and the method of Johnson \& Schaal (1957) modified by Singelton \& Rossi (1965). The results are for total phenols expressed in terms of $\mu \mathrm{M}$ of chlorogenic acid $\mathrm{g}^{-1}$ dry mass (d.m.). Chlorogenic acid was the standard used in these assays.

Condensed (catechol) tannins, after extraction with absolute methanol, were determined colorimetrically $(\lambda=500 \mathrm{~nm})$ using a colour reaction with vanillin in an acid medium (Price et al., 1978). These results were converted to $\mu \mathrm{M}$ catechin $\mathrm{g}^{-1} \mathrm{~d} . \mathrm{m}$.

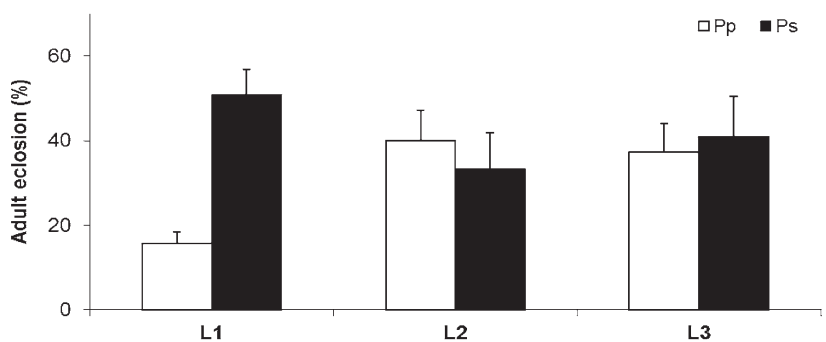

Fig. 5. Percentage of adults that emerged from pupae expressed in terms of the total number of moths that emerged from the pupae $(100 \%)$ that developed from larvae fed from the first instar L1 (Exp. I), L2 (Exp. II) and L3 (Exp. III) on either P. padus (Pp) or P. serotina (Ps). One-way ANOVA was used to determine whether the differences in the percentages of adult that emerged from pupae differed significantly. For L1 instar larvae $(P=0.0004)$, L2 $(P=0.49)$ and L3 $(P=0.75)$. Vertical bars represent standard errors (SE).

In Exp. I we measured leaf toughness using a leaf penetrometer FHT 801 (http://www.testequipmentdepot.com/general/garden/fht801.htm) on 20 April, 1 and 20 May and 6 July. From the shrubs analyzed in this study, we randomly selected three of each species that were growing under reduced light conditions, up to $50 \%$ of the light intensity measured outside the forest. The toughness $\left(\mathrm{gf} \mathrm{mm}^{-2}\right)$ of 50 leaves of each shrub based on two measurements of the leaf lamina between the lateral veins on the left and right half of the centre of each leaf. In the analysis the average value for each leaf was used.

\section{Statistical analyses}

Values presented on graphs are means of 12 replicates (batches of pupae for each species of shrub) for the duration (Fig. 4) and percentage of adults that emerged from pupae (Fig. 5). Total numbers of moths recorded in Exp. I for P. padus was 61 and for $P$. serotina 140. Similarly, total numbers recorded in Exp. II were 129 and 71, and in Exp. III 114 and 72, respectively. ANOVA of moth masses by sex and host plant in the three experiments (Fig. 6) are of measurements of 33 males (M) and 28 females (F) for P. padus, $81 \mathrm{M}$ and $59 \mathrm{~F}$ for P. serotina in Exp. I; $80 \mathrm{M}$ and 49 $\mathrm{F}$ for $P$. padus and $43 \mathrm{M}$ and $28 \mathrm{~F}$ for $P$. serotina in Exp. II and $66 \mathrm{M}$ and $48 \mathrm{~F}$ for $P$. padus and $43 \mathrm{M}$ and $29 \mathrm{~F}$ for $P$. serotina in Exp. III. Vertical lines associated with the points and columns in the figures indicate the values of the standard errors (SE) of the means (Figs 4-7, 11-12). We used repeated measures ANOVA to determine the influence of species of shrub on percentage of adults that emerged over time (Fig. 4) and Pillai's Trace test the interactions between time and species. For percentage adults that emerged from pupae (Figs 5 and 7) the Bliss arc sin formula was used (Snedecor \& Cochran, 1976). To assess the significance of the differences in total phenols, condensed tannins and toughness of the leaves of the two species of cherry we used one-way analysis of variance (ANOVA).

All analyses were done using statistical analysis software JMP 7.0.1 (SAS Institute, Cary, NC, USA).

\section{RESULTS}

\section{Insect performance}

In Exp. I in which egg clusters were placed at the same time on both shrubs of black cherry and bird cherry (3 April) the larvae survived for more than two days on only two of 12 shrubs of black cherry. At that time, the buds of $P$. serotina had just burst but the larvae died because of 


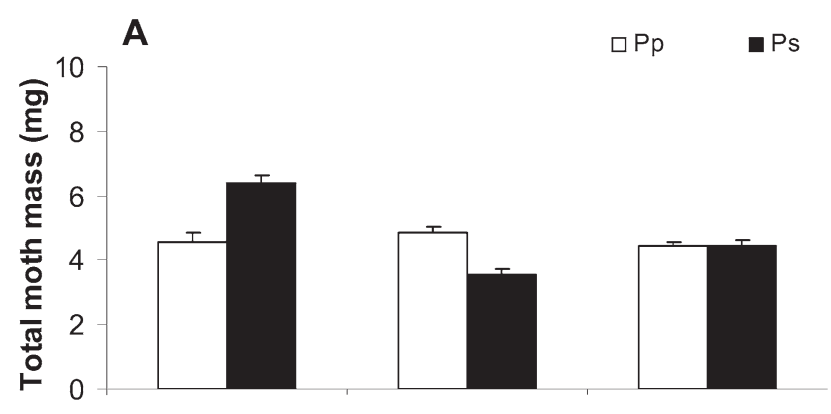

B
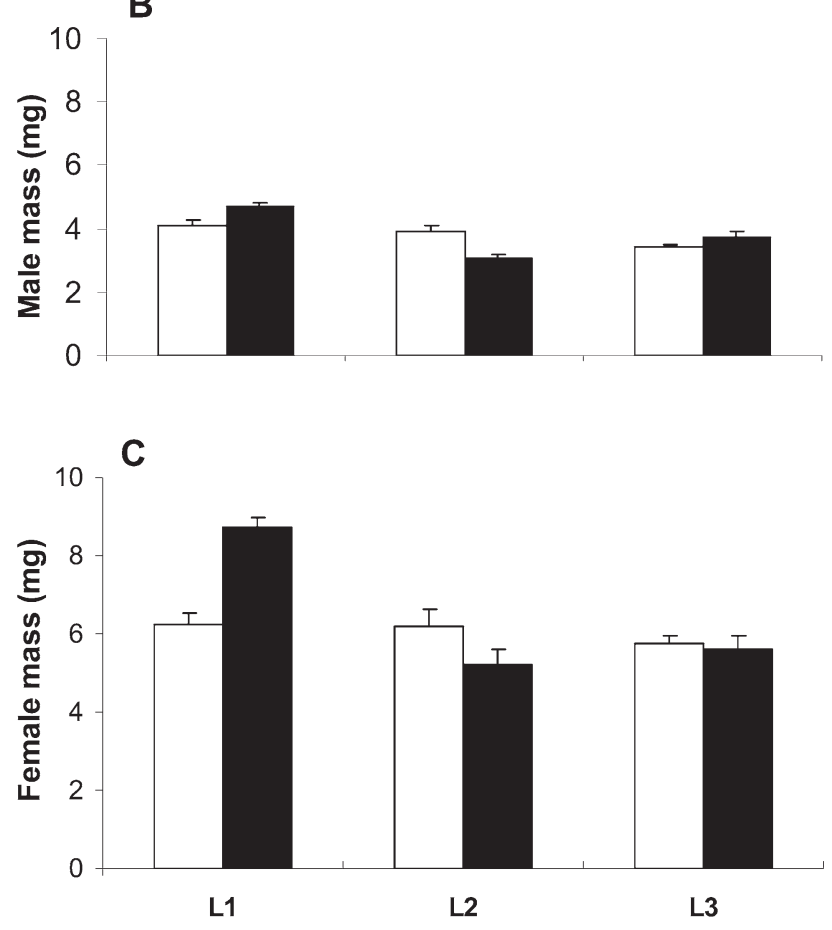

Fig. 6. Average mass of the moths of both sexes (A) and that of the males (B) and females (C) recorded in the experiments in which first instar larvae L1 (Exp. I), L2 (Exp. II) and L3 (Exp. III) were fed on either leaves of $P$. padus (Pp) or P. serotina (Ps). One-way ANOVA was used to determine whether the differences in average mass of both sexes differed (Fig. A) for L1 instar larvae $(P=0.0002), \mathrm{L} 2(P=0.0002)$ and L3 $(P=0.92)$, in male mass (Fig. B) for L1 instar larvae $(P=0.0042)$, L2 $(P=0.002)$ and L3 $(P=0.45)$, in female mass (Fig. C) for L1 instar larvae $(P=0.0007)$, L2 $(P=0.073)$ and L3 $(P=0.70)$. Vertical bars represent standard errors $(\mathrm{SE})$.

late spring frosts (16/17 April 2011), when the minimum temperature at night was $-7^{\circ} \mathrm{C}$. Over the period 3-17 April, rain fell on 7 days, including the first two days after the transfer of the clusters of eggs when 2.3 and $5.2 \mathrm{~mm}$ of rain fell, respectively. However, in the same experiment (Exp. I), larvae placed on black cherry shrubs two weeks later (17 April) than on bird cherry (3 April) survived and developed successfully. Finally, of the 12 shrubs of each species of cherry used in this experiment, $Y$. evonymellus moths emerged on all of the 12 shrubs of $P$. serotina but only 7 of those of P. padus. Based on the number of days from when the clusters of eggs were placed on the shrubs (3 April for P. padus and 17 April for P. serotina) adults began emerg-

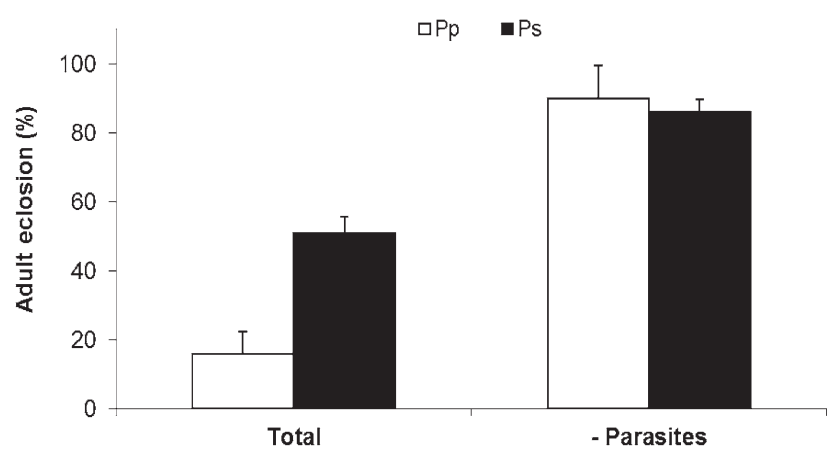

Fig. 7. Percentage of pupae from which moths emerged (left) and that corrected for pupal parasitism (right) of those that developed from larvae fed from the first instar (Exp. I) on either leaves of P. padus (Pp) or P. serotina (Ps). One-way ANOVA was used to determine whether the percentages that gave rise to adult moths $(P=0.0004)$ or were parasitized $(P=0.36)$ differed. Vertical bars represent standard errors (SE).

ing earlier on black cherry (Fig. 4A) and the period over which adults continued to emerge from pupae was longer by 13 days on P. serotina than on P. padus. In Exp. II, the larvae developed into moths on 9 shrubs of both species of cherry. In this experiment, adults emerged later on black cherry but the difference between the two species of cherry was smaller (5 days) and not statistically significant (Fig. 4B). For the larvae in the last stage in their development transferred to shrubs of black cherry (Exp. III), the difference in the time to adult emergence on the two species of cherry species was smallest (3 days), but adult emergence occurred significantly earlier on P. serotina (Fig. 4C). In this experiment, adults emerged on 10 shrubs of bird cherry and 8 of black cherry of the 12 shrubs of each species of cherry used. The average percentages of adult that emerged from pupae (Fig. 5), masses of male and female moths combined (Fig. 6A) and for males (Fig. 6B) and females (Fig. 6C) separately that were reared from clusters of eggs placed on shrubs of black cherry two weeks later than on bird cherry (Exp. I) are significantly greater for those reared on black cherry than on bird cherry. In the experiment in which the larvae were at an intermediate stage of development (Exp. II), the differences in the percentages of adults that emerged from pupae were not statistically significant (Fig. 5). The masses of the moths that as larvae fed on bird cherry were higher than those fed on black cherry (Fig. $6 \mathrm{~A}-\mathrm{C}$ ), and statistically significant for the combined average values of both sexes (Fig. 6A) and male moths (Fig. $6 \mathrm{~B})$. When the larvae from bird cherry were transferred to shrubs of black cherry at a very late stage in their development (Exp. III) there were no statistically significant differences in the percentage of adults that emerged from the pupae (Fig. 5) or in the masses of the moths (Fig. 6A-C). The percentages of adults emerging presented above are based on the number of moths that emerged from pupae and the total number of pupae (Fig. 5). The large differences in the percentage of adults that emerged in Exp. I, in which larvae at a very early stage in their development were transferred prompted us to examine the pupae. A 


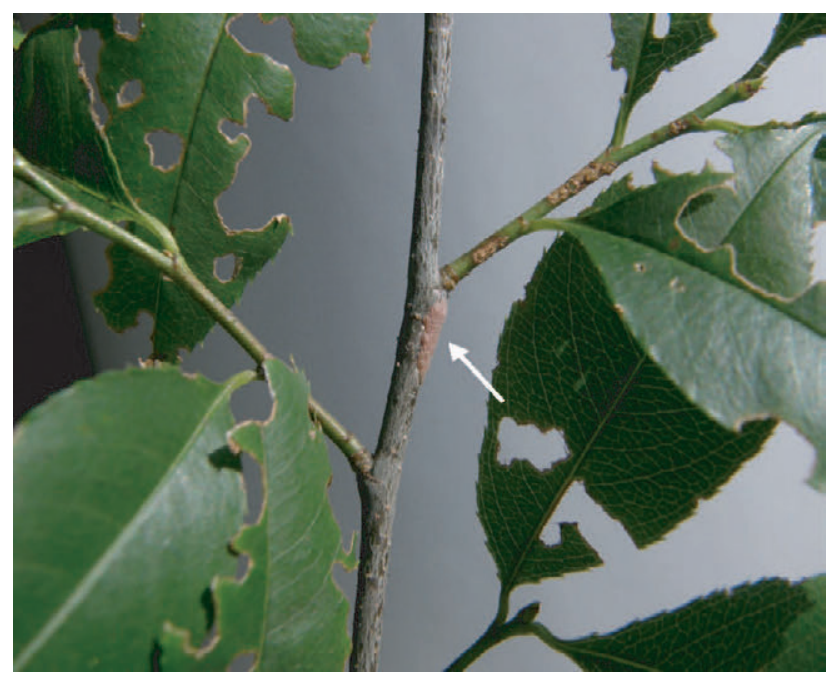

Fig. 8. Cluster of eggs of $Y$. evonymellus on a twig of P. serotina.

much higher number of the pupae reared as larvae on native bird cherry were parasitized than those reared on the non-native black cherry (Table 1). When the percentages of emergence of adults were corrected for pupal parasitism then they did not differ significantly for the larvae that fed on leaves of the two different species of cherry (Fig. 7). Only the effect of plant species on the percentage of moths emerging was analyzed. However, the parasitoids we found belonged to the family Ichneumonidae, order Hymenoptera: Itoplectis maculator, Pimpla turionella, Herpetostomus brunnicornis, Diadegma armillata, Phaenogenes invisor, Trichonotus varitarsus, Agrypon anxium and Lissonota sp.; a microdrile oligochaete family belonging to the Encythridae: Ageniaspis fuscicollis; a family of Hymenoptera, the Eulophidae: Tetrastichus evonymellae and a family of true flies belonging to the order Diptera, the Tachinidae: Bactromyia aurulenta. We did not evaluate the degree of parasitism in previous experiments (Exp. II and III). However, in the experiments in which larvae at a late stage in their development (L2 and L3) were used the percentages of adults that emerged from pupae on bird cherry and black cherry were similar (Fig. 5).

Because in previous years $Y$. evonymellus eggs were recorded on the stems of $P$. serotina we decided to make a preliminary quantitative assessment of such cases. For example, in spring 2012, we examined all the shrubs of Pru$n u s$ in the understory along a $100 \mathrm{~m}$ long transect through the forest, which consisted of mainly P. serotina and few $P$. padus (85 shrubs in total) and found $Y$. evonymellus eggs on 7 shrubs of $P$. serotina (P. Karolewski, pers. observ.,

TABLE 1. The total number of pupae, number of parasitized pupae, number of pupae not parasitized and number of moths that emerged in Exp. I.

\begin{tabular}{|c|c|c|c|c|}
\hline \multirow{2}{*}{$\begin{array}{l}\text { Host plant- } \\
\text { species }\end{array}$} & \multicolumn{4}{|c|}{ Number of pupae and moths } \\
\hline & $\begin{array}{l}\text { Total no. } \\
\text { of pupae }\end{array}$ & $\begin{array}{c}\text { No. of } \\
\text { parasitized pupae }\end{array}$ & $\begin{array}{l}\text { No. of pupae } \\
\text { not parasitized }\end{array}$ & $\begin{array}{l}\text { No. of } \\
\text { moths }\end{array}$ \\
\hline P. padus & 388 & 320 & 68 & 61 \\
\hline P. serotina & 276 & 113 & 163 & 140 \\
\hline
\end{tabular}

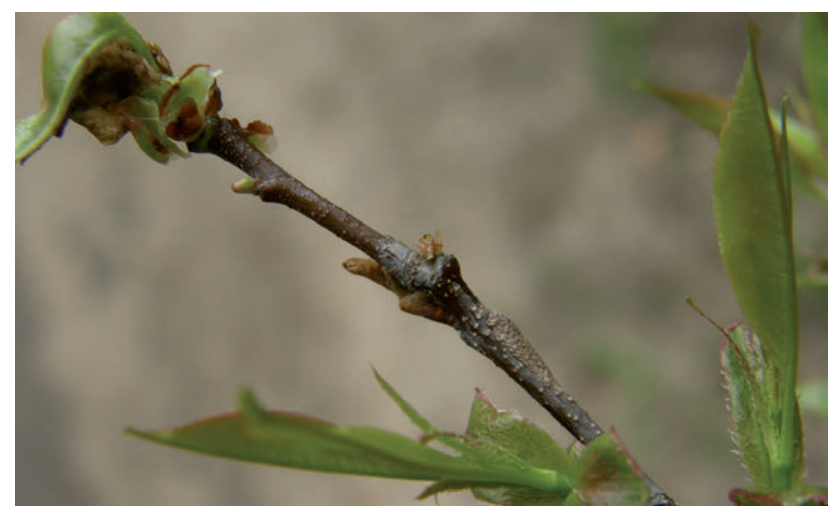

Fig. 9. Larvae and cluster of eggs of Y. evonymellus on twig of $P$. serotina early in spring.

Fig. 8). The larvae feeding on the leaves of this species (Fig. 9) in most cases disappeared after 1-3 weeks, possibly because they were washed off by heavy rain or killed by a spring frost, however on two of the shrubs the larvae successfully completed their development and produced pupae from which adults emerged (Fig. 10).

\section{Foliar chemistry and leaf toughness}

We wanted to determine whether chemical defence determines the choice of host plant by $Y$. evonymellus. The leaves of black cherry are as good a source of food for $Y$. evonymellus as those of bird cherry. It is likely that this is because during the feeding period the leaves of both species have low concentrations of defensive compounds (phenolics and condensed tannins). In the shrubs studied during this period (from mid-April to mid-June) both the level of total soluble phenols (Fig. 11A) and condensed tannins (Fig. 11B) were lower in the leaves of P. serotina than $P$. padus.

In addition, we checked whether leaf toughness determined the choice of bird cherry as a host by Y. evonymellus. For some time after the start of the feeding by larvae black cherry leaves were significantly less tough than those of bird cherry and only at the end of this period were the black cherry leaves tougher (Fig. 12).

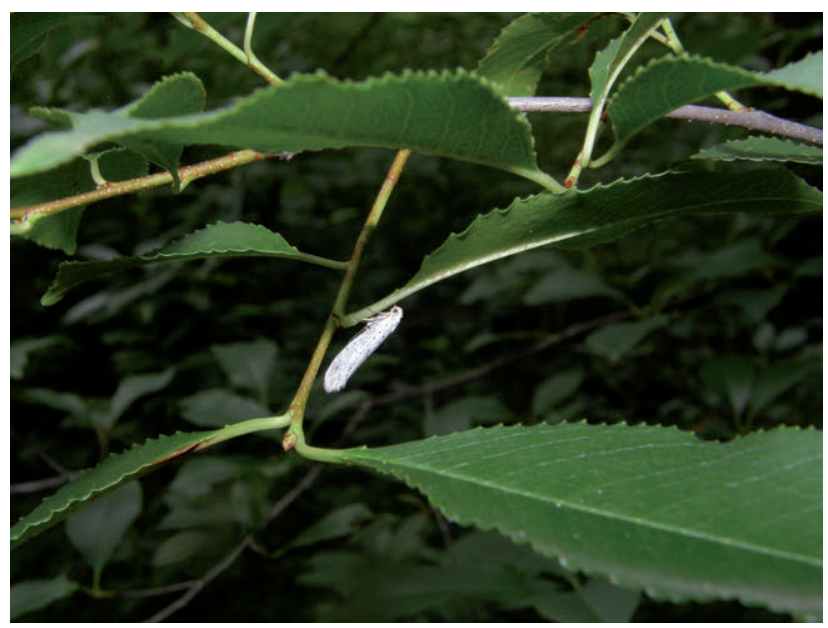

Fig. 10. Moth of Y. evonymellus on twig of P. serotina. 

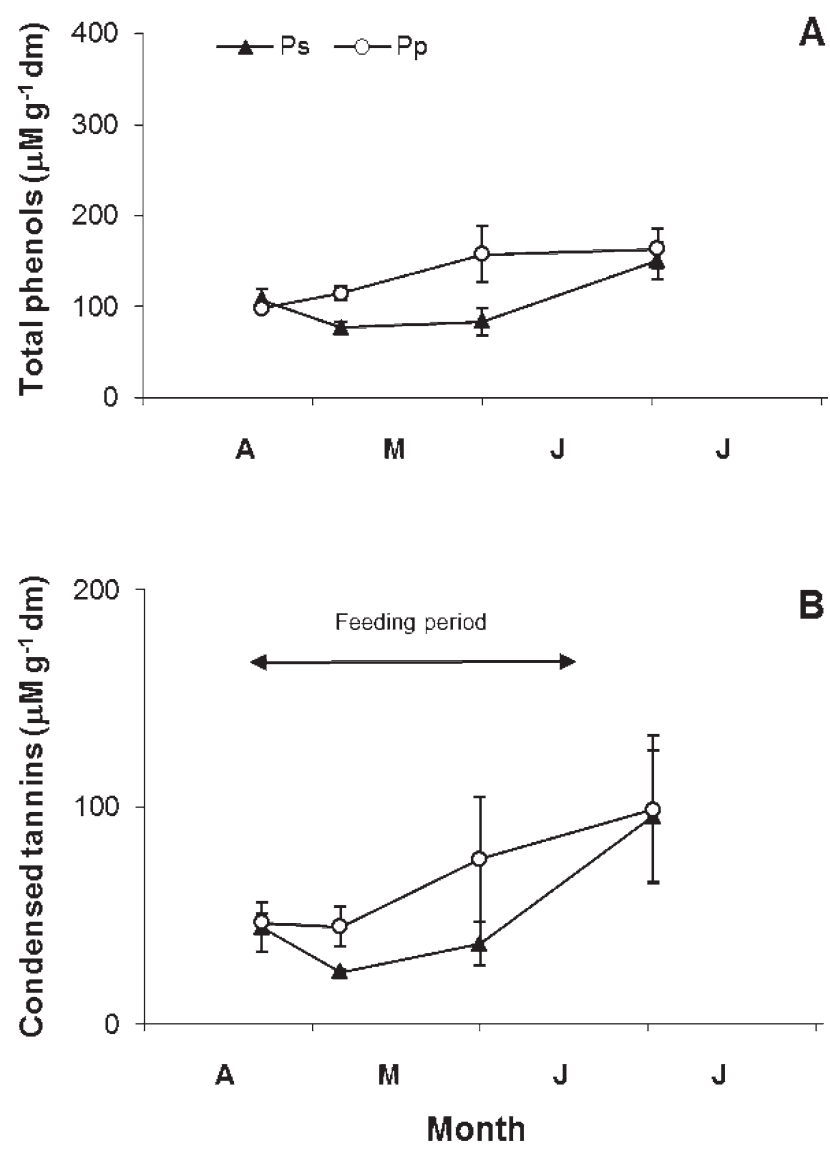

Fig. 11. Concentration of total soluble phenols (A), expressed in terms of chlorogenic acid, and condensed tannins (B), expressed in terms of catechin, in leaves of the P. padus (Pp) and $P$. serotina (Ps) used in Exp. I. A one-way ANOVA was used to determine whether the differences between species were significant. The significance of the differences between species were for phenols (A) in the different months: $P=0.39, P=0.004, P=0.057$ and $P=0.66$, and for tannins (B): $P=0.87, P=0.033, P=0.22$, $P=0.95$. Vertical bars represent standard errors (SE).

\section{DISCUSSION}

This study has shown that the larvae of $Y$. evonymellus, which is widely thought to be monophagous and feeding only on native bird cherry, can successfully feed and develop on the leaves of non-native black cherry. Larval performance, in terms of the mass achieved (Fig. 6), may be even better on the non-native black cherry than the native bird cherry. With the maturation and ageing of the leaves, the concentration of compounds necessary for the growth and development of insects, such as nitrogen, phosphorous and water, diminish and the structure of the leaves change so that they become more difficult for insects to eat (Ayres \& MacLean Jr., 1987). As shown in this study, this may cause larvae in the early stages of their development to move from bird cherry to black cherry. The results presented indicate that this is beneficial for the larvae, but only if they change host plant at the beginning of their development (Fig. 5). In Exp. I in which the larvae reared on $P$. serotina started developing two weeks later they developed at higher ambient temperatures than the larvae reared on $P$. padus. This could account for their faster development and

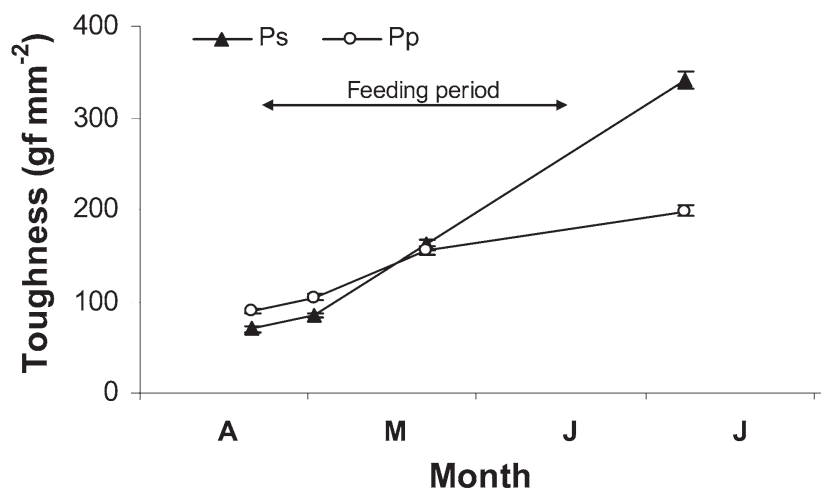

Fig. 12. Leaf toughness of P. padus (Pp) and P. serotina (Ps) recorded for the plants used in Exp. I. A one-way ANOVA was used to determine whether the differences between species in each month were significant. The significance of the differences between species for the different months is: $P<0.0001, P<0.0001$, $P=0.38$ and $P<0.0001$. Vertical bars represent standard errors (SE).

that larvae initially reared on P. padus (Exp. II and Exp. III) did not subsequently perform better on P. serotina. The benefit of moving to black cherry is also consistent with the strategy of avoiding natural enemies such as parasites (Awmack \& Leather, 2002; Harvey \& Fortuna, 2012). It is likely that the $Y$. evonymellus larvae were parasitized early in their development. There were differences in percentage of adults that emerged on the two hosts when eggs were transferred to $P$. serotina (Exp. I). This indicates that the parasites did not attack the eggs but mostly larvae and not those at the very earliest stages in their development. It is also possible that the smaller size of the larvae on $P$. serotina than on $P$. padus might mean they were less attractive (less food) for parasites, as suggested by Rivero and West (2002) for a parasitic wasp. On the other hand, the food source for parasites could be greater at a later stage in the development of the larvae on $P$. serotina. A similar effect of invasive plants on herbivore-parasitoid interactions is reported by Harvey \& Fortuna (2012). The dependence of the parasitoids of $Y$. evonymellus on its host plant needs to be determined. There are studies on the parasitism of $Y$. evonymellus, but only on $P$. padus (Pyörnilä \& Pyörnilä, 1979). We plan to determine the composition and abundance of parasites in natural habitats where the two host plant species occur together and those where only P. seroti$n a$ occurs, to which we will transfer stems bearing clusters of eggs of $Y$. evonymellus.

We believe this conclusion is correct, but it is possible that differences in weather in the years the experiments were done affected the results, especially the differences in temperature and frequency and intensity of precipitation. In addition, it is possible that storing the larvae for two weeks in unnatural (artificial) low temperature conditions (Exp. I), rather than developing naturally on P. serotina, may have affected their development.

It is likely that the main problem for $Y$. evonymellus in utilizing black cherry as a host is that $P$. serotina produces its leaves later in the year than P. padus. Our field observations indicate that the $Y$. evonymellus larvae that fed on 
$P$. serotina previously fed for ca. 1-2 weeks on $P$. padus leaves in areas where the branches of these two species come into contact with one another. Larvae that had spent all their development feeding directly on $P$. serotina leaves were rare. As described above, recently there has been an increase in the numbers of clusters of eggs of $Y$. evonymellus recorded on black cherry but few of the larvae survive. $P$. serotina leaves develop later than those of $P$. padus and as a consequence the larvae starve, which accounts for the high percentage mortality. In addition, the larvae that survived on $P$. serotina developed slowly, were more susceptible to adverse environmental factors (low temperature, rainfall) and had more difficulty shaping the smaller and tougher leaves of $P$. serotina to form shelters to protect them against the rain. In addition, the slower developing larvae on P. serotina spun fragile webs that also proved less effective at protecting them against the adverse effects of rain and low temperatures.

It is possible that the observations described are associated with differences in spring temperature caused by global warming, which results in phenological differences in the development of plants that affect the interactions between them and herbivorous insects (Walther et al., 2002; Walther, 2004). Thus, the results of our studies may be an early indication that due to climate change $Y$. evonymellus is currently becoming better at using the leaves of $P$. serot $i$ $n a$ as a food source. P. serotina is more thermophilous than $P$. padus and much less demanding in terms of its humidity requirements (Ellenberg et al., 1992). The consequence of climate warming is the occurrence of extremely high temperatures and the drying out of soils in summer. P. serotina is better able to tolerate such conditions and therefore is becoming more invasive and displacing P. padus. We think that such changes will enable $Y$. evonymellus to adapt to living on a new host plant. It is likely that the new host will be $P$. serotina the leaves of which are equally suitable to those of $P$. padus for the development larvae of this species. However, it is too early to predict to what extent $Y$. evonymellus will adapt to using black cherry leaves as food because attack by this herbivore may affect $P$. serotina success as an invasive species in Europe.

Black cherry is extremely resistant to various leaf mass reducing factors, such as insects (Petersen, 1960; Halarewicz \& Jackowski, 2011), artificial defoliation (Karolewski et al., 2010), mechanical damage of branches or even complete removal of the aboveground part of shrubs (Mulligan \& Mundro, 1981; Closset-Kopp et al., 2007; Annighöfer et al., 2012). Therefore, even the increasing use of black cherry leaves as food by $Y$. evonymellus may not have a significant effect on black cherry. It would, however, extend the range of the food supply of this insect and as a result it could become more wide spread in its distribution. This scenario augurs an unfavourable situation for bird cherry. This species is a very attractive food source for many species of native herbivorous insects (Gifford, 1959; Jaroviš et al., 2005). In addition, bird cherry is more demanding in terms of the nutrient content of the soil and soil moisture than black cherry (Ellenberg et al., 1992). Thus, the widely reported direct negative influence of $Y$. evonymellus on bird cherry, is likely to increase in the future as a result of the indirect negative effect of the increasing insect population resulting from the incorporation of black cherry in its food source. Examples of non-native invasive plants becoming supplementary food sources for native insects are given in the review by Harvey \& Fortuna (2012). An important question that remains unanswered is whether the $Y$. evonymellus that develop on the leaves of black cherry are reproductively viable. Menken et al. (1992) cite examples of the effect of feeding on plants other than the main host in reducing the fecundity of some species of Yponomeuta. As reported by Kooi et al. (1991), for species of Yponomeuta, the nature of the food of the larva does not affect where the species lays its eggs, but does determine the species of host plant. Furthermore, Bakker et al. (2008) show no preference for host plants as places for mating for two species of Yponomeuta - the oligophagous Yponomeuta padellus and monophagous Yponomeuta cagnagellus. Our field observations indicate that females of $Y$. evonymellus avoid laying eggs on $P$. serotina as no egg clusters of this moth were recorded on individual shrubs of $P$. serotina growing among $P$. padus shrubs. All the egg clusters of ermine moth on $P$. serotina were recorded only in places where this species was numerous, with rare individuals of $P$. padus scattered among them. Most moths of the genus Yponomeuta do not disperse far from where they emerge (M. Brookes \& R. Butlin, pers. commun., after Menken et al., 1992). Therefore, our observations of $Y$. evonymellus living on shrubs of $P$. serotina in these conditions confirm the conclusion of Menken et al. (1992) that colonization rather than coevolution may explain host association in Yponomeuta species. This aspect of the ermine moth's adaptation to a new host plant needs further study.

We think that the main reason why $Y$. evonymellus does not infest black cherry is that its leaves appear later than those of bird cherry. In addition, the chemical defence of the leaves (Fig. 11) and the greater toughness of leaves of black cherry do not determine the choice of host. The latter could be important, but only for final stage larvae (Fig. 12). In the field ermine moth larvae never feed on $P$. serotina growing in direct sunlight, but on those growing in the shade or at least in reduced light conditions. The leaves of these plants are relatively thin and their toughness is similar to that of the sun-leaves of P. padus, on which the larvae successfully feed. A low concentration of total phenols and condensed tannins and high value of SLA indicating a low toughness of leaves, differentiate heavily damaged shade leaves from the less damaged sun leaves (Karolewski et al., 2013). Defoliation and insect performance are associated with leaf toughness (Peeters et al., 2007; Dominy et al., 2008).

In conclusion, we found that the leaves of black and bird cherry are both good quality foods for $Y$. evonymellus. It is likely that this is due to the fact that during the feeding period (April to June), the concentrations of defensive compounds such as phenolics and condensed tannins are lower and the toughness of the leaves of the invasive $P$. serotina 
are similar to those of the native $P$. padus. Our results also indicate that the prevalent choice of native bird cherry by $Y$. evonymellus is due mainly to differences in the leaf phenology of the two species of cherry, in particular, the later leaf development of black cherry than bird cherry. The planned experiment using shrubs of $P$. serotina forced to produce their leaves at the same time as $P$. padus infested with eggs of $Y$. evonymellus collected from $P$. padus, should confirm this.

ACKNOWLEDGEMENTS. This work was funded by the Ministry of Sciences and Higher Education, Poland (grant no. N N304 037640). We thank L. Frelich of the University of Minnesota, USA, for reviewing the final version of the manuscript and A. Grzybek and A. Majewicz for their technical assistance with the experiments.

\section{REFERENCES}

Abrams M.D., Kloeppel B.D. \& KubisKe M.E. 1992: Ecophysiological and morphological responses to shade and drought in two contrasting ecotypes of Prunus serotina. - Tree Physiol. 10: $343-355$.

Annighöfer P., Schall P., Kawaletz H., Mölder I., Terwei A., Zerbe S. \& Ammer C. 2012: Vegetative growth response of black cherry (Prunus serotina) to different mechanical control methods in a biosphere reserve. - Can. J. For. Res. 42 2037-2051.

Awmack C.S. \& Leather S.R. 2002: Host plant quality and fecundity in herbivorous insects. - Annu. Rev. Entomol. 47: 817-844.

Ayres M.P. \& MacLean JR. S.F. 1987: Development of birch leaves and their growth energetics of Epirrita autumnata (Geometridae). - Ecology 68: 558-568.

Bakker A.C., Roessingh P. \& Menken S.B.J. 2008: Sympatric speciation in Yponomeuta: no evidence for host plant fidelity. - Entomol. Exp. Appl. 128: 240-247.

Chaneton E.J., Maziá C.N. \& Kitzberger T. 2010: Facilitation vs. apparent competition: insect herbivory alters tree seedling recruitment under nurse shrubs in a steppe-woodland ecotone. - J. Ecol. 98: 488-497.

Closset-Kopp D., Chabrerie O., Valentin B., Delachapelle H. \& Decoce G. 2007: When Oskar meets Alice: Does a lack of trade-off in $\mathrm{r} / \mathrm{K}$-strategies make Prunus serotina a successful invader of European forest? - For. Ecol. Manag. 247: 120130.

Dominy J., Grubb P.J., Jackson R.V., Lucas P.W., Metcalfe D.J., SVENNING J-.C. \& TURNER I.M. 2008: In tropical lowland rain forests monocots have tougher leaves than dicots, and include a new kind of tough leaf. - Ann. Bot. 101: 1363-1377.

Ellenberg H., Weber H.E., Düll R., Wirth V., Werner W. \& Paulissen D. 1992: Zeigerwerte von Pflanzen in Mitteleuropa. - Scripta Geobot. 18: 3-258.

FleCKer A.S. \& Allan J.D. 1984: The importance of predation, substrate and spatial refugia in determining lotic insect distributions. - Oecologia 64: 306-313.

Fowells H.A. 1965: Silvics of Forest Trees of the United States. Agriculture Handbook 271, USDA Forest Service, Washington, DC, pp. 1-762.

GifFORD D. 1959: Notes on Scottish woodland insects: 1. The small ermine moth, Yponomeuta evonymella (L.) (Lepidoptera: Yponomeutidae). - Scot. For. 13: 142-143.

Halarewicz A. \& JACKOWSKI J. 2011: Leaf damage of the black cherry, Prunus serotina Ehrh., by the leaf beetle, Gonioctena quinquepunctata Fabr.: an accidental foraging on a neophytic host, or an established trophic link? — Pol. J. Ecol. 59: 589597.

Hamilton W.T., McGinty A., Ueckert D.N., Hanselka C.W. \& Lee M.R. 2004: Brush Management: Past, Present, Future. Texas A\&M University Press, College Station, 282 pp.

Harvey J.A. \& Fortuna T.M. 2012: Chemical and structural effects of invasive plants on herbivore-parasitoid/predator interactions in native communities. - Entomol. Exp. Appl. 144: 14-26.

Henriksson J., Haukioja E., Ossipov V., Osipova S., Sillsnpää S., Kaspari L. \& Pihlaja K. 2003: Effects of host shading on consumption and growth of the geometrid Epirrita autumnata: interactive roles of water, primary and secondary compounds. - Oikos 103: 3-16.

Jaroviš J., TAMmaru T. \& KäÄR M. 2005: Oviposition in an eruptive moth species, Yponomeuta evonymellus, is insensitive to the population density experienced during the larval period. Entomol. Exp. Appl. 115: 379-386.

JoHnSON G. \& SchaAl L.A. 1957: Accumulation of phenolic substances and ascorbic acids in potato tuber tissue upon injury and their possible role in disease and resistance. - Am. Potato J. 34: 200-202.

Karolewski P., Zadworny M., Mucha J., Napierala-Filipiak A. \& OleKsyn J. 2010: Link between defoliation and root vitality in five understory shrubs with different resistance to insect herbivores. - Tree Physiol. 30: 969-978.

Karolewski P., Giertych M.J., Żmuda M., Jagodziński A.M. \& OLEKSYN J. 2013: Season and light affect constitutive defenses of understory shrub species against folivorous insects. - Acta Oecol. 53: 19-32.

Knight K.S., Oleksyn J., Jagodzinski A.M., Reich P.B. \& KasproWICZ M. 2008: Overstory tree species regulate colonization by native and exotic plants: a source of positive relationships between understory diversity and invasibility. - Divers. Distrib. 14: 666-675.

Kooi R.E., van de Water T.P.M. \& Herrebout W.M. 1991: Food acceptable by a monophagous and an oligophagous insect in relation to seasonal changes in host plant suitability. - Entomol. Exp. Appl. 59: 111-122.

Koricheva J., NykÄnen H. \& Gianoli E. 2004: Meta-analysis of trade-offs among plant antiherbivore defenses: are plants jacksof-all-trade, masters of all? - Am. Nat. 163: E64-E75.

LEATHER S.R. 1985: Does the bird cherry have its 'fair share' of insect pests? An appraisal of the species-area relationships of the phytophagous insects associated with British Prunus species. - Ecol. Entomol. 10: 43-56.

LEATHER S.R. 1986: Insects on bird cherry 1: the bird cherry ermine moth, Yponomeuta evonymellus (L.) (Lepidoptera: Yponomeutidae). - Entomol. Gaz. 37: 209-215.

LEATHER S.R. 1988: Insects on bird cherry 2: the bird cherry oat aphit, Rhopalosiphum padi (L.) (Homoptera: Aphididae). Entomol. Gaz. 39: 89-97.

LEATHER S.R. 1994: Insects on bird cherry 3: the chrysomelid beetle, Phytodecta pallida (L.) (Coleoptera: Chrysomelidae). Entomol. Gaz. 45: 73-76.

Leather S.R. 1996: Prunus padus L. - J. Ecol. 84: 125-132.

LeATHER S.R. \& Lehti J.P. 1982: Abundance and distribution of Yponomeuta evonymellus (Lepidoptera, Yponomeutidae) in Finland during 1981. — Notul. Entomol. 62: 93-96.

Menken S.B.J., Herrebout W.M. \& Wiebes J.T. 1992: Small ermine moths (Yponomeuta) - their host relations and evolution. - Annu. Rev. Entomol. 37: 41-66.

Molina-Montenegro M.A., Ávila P., Hurtado R., Valdivia A.I. \& Gianoli E. 2006: Leaf trichome density may explain herbivory patterns of Actinote sp. (Lepidoptera: Acraeidae) on 
Liabum mandonii (Asteraceae) in a montane humid forest (Nor Yungas, Bolivia). - Acta Oecol. 30: 147-150.

Mulligan G.A. \& Munro D.B. 1981: The biology of Canadian weeds 51. Prunus virginiana L. and P. serotina Ehrh. - Can. J. Plant Sci. 6: 977-992.

Pairon M., Petitpierre B., Campbell M., Guisan A., Broennimann O., Baret P.V., Anne-Jacquemart A.L. \& Besnard G. 2010: Multiple introductions boosted genetic diversity in the invasive range of black cherry (Prunus serotina; Rosaceae). Ann. Bot. 105: 881-890.

Paquette A., Bouchard A. \& Cogliastro A. 2007: Morphological plasticity in seedlings of three deciduous species under shelterwood under-planting management does not correspond to shade tolerance ranks. - For. Ecol. Manag. 24: 278-287.

Peeters P.J., Sanson G. \& Read J. 2007: Leaf biomechanical properties and the densities of herbivorous insect guilds. Funct. Ecol. 21: 246-255.

Petersen B.B. 1960: Angreb af penselspinderen pa Ulborg skovdistrikt. [Attack by Orgyia antiqua in the Ulborg forest district.] - Dansk Skovfor. Tidsskr. 45: 94-100.

Price M.L., van Scoyoc S. \& Butler L.G. 1978: A critical evaluation of the vanillin reaction as an assay for tannin in sorghum grain. - J. Agr. Food Chem. 26: 1214-1218.

PYÖRNILÄ M. \& PYÖRNILÄ A. 1979: Role of parasitoids in terminations of a mass occurrence of Yponomeuta evonymellus (Lepidoptera, Yponomeutidae) in northern Finland. - Notul. Entomol. 59:137-138.

Rivero A. \& West S.A. 2002: The physiological costs of being small in a parasitic wasp. - Evol. Ecol. Res 4: 407-420.

Scholz H. \& Scholz I. 1995: Prunoideae. In Conert H.J. et al. (eds): Gustav Hegi Illustrierte Flora von Mitteleuropa. Band IV. Teil 2B. Spermatophyta; Angiospermae: Dicotyledones 2(3). 2nd ed. Blackwell Wissenschafts, Berlin, pp. 446-470.

Singelton V.I. \& Rossi J.A. 1965: Colorimetry of total phenolics with phosphomolybdic-phosphotungstic acid reagent. - Am. J. Enol. Vitic. 16: 144-158.
Snedecor G.W. \& Cochran W.G. 1976: Statistical Methods. 6th ed. The Iowa State University Press, Ames, pp. 327-329.

Starfinger U. 1991: Population biology of an invading tree species - Prunus serotina. In Seitz A. \& Loeschcke V. (eds): Species Conservation: A Population Biological Approach. Birkhauser, Basek, pp. 171-184.

StARFINGER U. 1997: Introduction and naturalization of Prunus serotina in Central Europe. In Brock J.H., Wade M., Pysek P. \& Green D. (eds): Plant Invasions: Studies from North America and Europe. Backhuys, Leiden, pp. 161-171.

Starfinger U., Kowarik I., Rode M. \& Schepker H. 2003: From desirable ornamental plant to pest to accepted addition to the flora? The perception of alien tree species through the centuries. - Biol. Invasions 5: 323-335.

Uusitalo M. 2004: European Bird Cherry (Prunus padus L.) A Biodiverse Wild Plant for Horticulture. Agrifood Research Report 61, MTT Agrifood Research Finland, Jokioinen, 82 pp.

Vanhellemont M., Verheyen K., De Keersmaeker L., VandeKerkhove K. \& Hermy M. 2009: Does Prunus serotina act as an aggressive invader in areas with a low propagule pressure? - Biol. Invas. 11: 1451-1462.

Walther G.R. 2004: Plants in a warmer world. - Perspect. Plant Ecol. Evol. Syst. 6: 169-185.

Walther G.R., Post E., Convey P., Menzel A., Parmesank C., Beebee T.C.J., Fromentin J.M., Hoegh-Guldberg O. \& BairLEIN F. 2002: Ecological responses to recent climate change. - Nature 416: 389-395.

Zerbe S. \& Wirth P. 2006: Non-indigenous plant species and their ecological range in Central European pine (Pinus sylvestris L.) forests. - Ann. For. Sci. 63: 189-203.

Żmuda M., Karolewski P., Giertych M.J., ŻytKowiak R., Bąkowski M., Grzebyta J. \& Oleksyn J. 2008: The effect of light conditions on leaf injury in underbrush shrubs caused by leaf-eating insects. - Acta Sci. Pol. Silv. Colendar. Rat. Ind. Lignar. 7: 47-57.

Received February 20, 2013; revised and accepted December 16, 2013 Prepublished online March 6, 2014 